\title{
Root Contact between Maize and Alfalfa Facilitates Nitrogen Transfer and Uptake Using Techniques of Foliar ${ }^{15} \mathrm{~N}$-Labeling
}

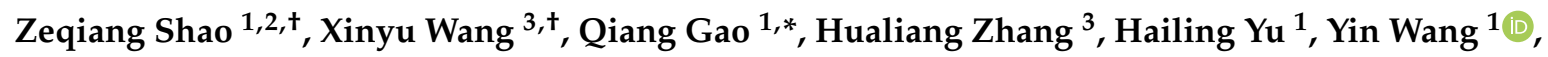 \\ Jinjing Zhang ${ }^{1}$, Jamal Nasar ${ }^{1}$ and Yingzhi Gao ${ }^{3, *}$ \\ 1 College of Resources and Environmental Sciences/Key Laboratory of Sustainable Utilization of SoilResources \\ in the Commodity Grain Bases in Jilin Province, Jilin Agricultural University, Changchun 130118, China; \\ zeqiangshao@126.com (Z.S.); Yuhl292@163.com (H.Y.); wy1986410@163.com (Y.W.); \\ zhangjinjing@126.com (J.Z.); Jamalnasar554@gmail.com (J.N.) \\ 2 Popularization Center of Agricultural Technology of Jilin City, Jilin 132013, China \\ 3 Key Laboratory of Vegetation Ecology, Institute of Grassland Science, Northeast Normal University, \\ Changchun 130024, China; wangxy163@nenu.edu.cn (X.W.); zhanghl221@nenu.edu.cn (H.Z.) \\ * Correspondence: gyt199962@163.com (Q.G.); Gaoyz108@nenu.edu.cn (Y.G.) \\ + Authors contributed equally to this work.
}

Received: 21 January 2020; Accepted: 3 March 2020; Published: 5 March 2020

\begin{abstract}
Belowground nitrogen $(\mathrm{N})$ transfer from legumes to non-legumes provides an important $\mathrm{N}$ source for crop yield and $\mathrm{N}$ utilization. However, whether root contact facilitates $\mathrm{N}$ transfer and the extent to which $\mathrm{N}$ transfer contributes to crop productivity and $\mathrm{N}$ utilization have not been clarified. In our study, two-year rain shelter experiments were conducted to quantify the effect of root contact on $\mathrm{N}$ transfer in a maize/alfalfa intercropping system. $\mathrm{N}$ transfer occurred mainly one direction from alfalfa to maize during the growth period. Following the N0 treatment, the amount of $\mathrm{N}$ transfer from alfalfa to maize was $204.56 \mathrm{mg} \mathrm{pot}^{-1}$ with no root barrier and $165.13 \mathrm{mg} \mathrm{pot}^{-1}$ with a nylon net barrier, accounting for $4.72 \%$ and $4.48 \%$ of the total $\mathrm{N}$ accumulated in maize, respectively. Following the $\mathrm{N} 1$ treatment, the amount of $\mathrm{N}$ transfer from alfalfa to maize was $197.70 \mathrm{mg} \mathrm{pot}^{-1}$ with no root barrier and $139.04 \mathrm{mg} \mathrm{pot}^{-1}$ with a nylon net barrier, accounting for $3.64 \%$ and $2.36 \%$ of the total $\mathrm{N}$ accumulated in the maize, respectively. Furthermore, the amount of $\mathrm{N}$ transfer without no root barrier was 1.24-1.42 times higher than that with a nylon net barrier regardless of the level of $\mathrm{N}$ addition. Our results highlight the importance and the relevance of root contact for the enhancement of $\mathrm{N}$ transfer in a maize/alfalfa intercropping system.
\end{abstract}

Keywords: intercropping; ${ }^{15} \mathrm{~N}$ foliar labeling; root contact; $\mathrm{N}$ transfer; $\mathrm{N}$ utilization

\section{Introduction}

The north-eastern area of China is characterized as a semi-arid and temperate climatic region. The farming and pastoral area in this region represents an important grain commodity and animal husbandry base and covers $3.83 \times 10^{5} \mathrm{~km}^{2}$. This area plays a key role in the development of Chinese agriculture and animal husbandry. However, a long period of intensive agricultural production has led to serious problems, including soil degradation, chemical pollution, and the loss of biodiversity in the agricultural soil $[1,2]$. Furthermore, low vegetation cover and wind erosion have deteriorated the ecosystem in this region. Therefore, it is crucial to adjust the planting structure and reduce the amount of chemical fertilizer used in this region.

Compared to typical Chinese agriculture practices, intercropping can increase nutrient utilization efficiency and achieve optimal economic output as well as income [3-6]. These benefits occur 
because $\mathrm{N}$ transfer between legumes and cereals can be an important source of nitrogen for cereal crops $[7,8]$. $\mathrm{N}$ transfer has been studied thoroughly in many cereal-legume intercropping systems, e.g., bean/maize [9], pea/barley [10], faba/wheat [11], peanut/rice [7], manures/lettuce [12], pea/maize [13], soybean/maize [14], and bean/garlic [15]. Literature data show that rates of $\mathrm{N}$ transfer range from 0 to $80 \%$ from legumes to cereal in mixed stands, depending on the legume species and the cultivar [16-18]. In the north-eastern area of China, maize (Zea mays L.) is a major food crop grown in farming and pastoral areas. Alfalfa (Medicago sativa L.) is a commonly grown perennial forage legume in this area [19] because it is high yielding, rich in nutrients, easy to digest, and palatable. Recent studies suggested that maize/alfalfa intercropping is a successful crop management strategy that could significantly enhance yield and economic benefits $[5,20]$. However, it is still unclear whether $N$ transfer exists in an alfalfa/maize intercropping system.

Previous studies found that root contact plays an important role in the transfer of N. For example, one study revealed that $\mathrm{N}$ transfer from faba bean to the associated wheat without barrier was significantly higher than that with the nylon net barrier [11]. Meng et al. also found that $\mathrm{N}$ transfer was significantly increased under the no barrier treatment compared with the solid barrier in the soybean/maize intercropping system [21]. In addition, the amount of $\mathrm{N}$ transferred is also closely related to the supply of soil $\mathrm{N}$ fertilizer. For example, in peanut/rice intercropping systems, the amount of $\mathrm{N}$ transferred was greater, and its effects were more pronounced under low $\mathrm{N}$ conditions than under high $\mathrm{N}$ conditions [7]. Furthermore, the rate of $\mathrm{N}$ transfer from peanut to rice was decreased significantly with an increase in the $\mathrm{N}$ supply levels [7,22]. However, there have been no attempts to explore the effects of root contact on nitrogen transfer between alfalfa and maize at two different $\mathrm{N}$ levels.

It has been reported that belowground $\mathrm{N}$ transfer from legumes provides an important $\mathrm{N}$ source for coexisting cereals [23]. For example, the $\mathrm{N}$ transferred from faba bean to wheat corresponded to $15 \%$ of the total $\mathrm{N}$ uptake by wheat in a faba bean/wheat intercropping system [11]. Paddy rice/peanut intercropping significantly improved dry matter and $\mathrm{N}$ uptake in rice because $2-3.5 \%$ of the $\mathrm{N}$ fixed by the peanut was transferred to the rice [7]. One study revealed that root contact improved $\mathrm{N}$ uptake by $26.3 \%$ [24]. Zhang et al. found that soybean/maize intercropping could improve $\mathrm{N}$ transfer and uptake in the karst region of Southwest China [14]. However, it is unclear whether the high nitrogen transfer is associated with the total $\mathrm{N}$ uptake under maize/alfalfa root contact conditions. Therefore, two-year rain shelter experiments were carried out in a maize/alfalfa root separation experiment with the following objectives: (1) to clarify the effect of root contact on $\mathrm{N}$ transfer from alfalfa to maize at two $\mathrm{N}$ levels and (2) to determine the relationship between $\mathrm{N}$ transfer and total $\mathrm{N}$ uptake.

\section{Materials and Methods}

\subsection{Site Description}

Two pot experiments were conducted in the new rain shelter of the College of Resources and Environment of Jilin Agricultural University from 2015 to $2016\left(125^{\circ} 24^{\prime} 50.38^{\prime \prime}\right.$ E and $43^{\circ} 48^{\prime} 28.59^{\prime \prime} \mathrm{N}$, 248.5 masl). The climate in this area belongs to the north temperate continental monsoon category with four distinct seasons and moderate semi-arid characteristics. The annual frost-free period is $120-160$ days, and the growing degree days $\left(\geq 10^{\circ} \mathrm{C}\right)$ are characterized by a temperature of $2200-3000{ }^{\circ} \mathrm{C}$. The final frost and the first frost occur in April and September, respectively. The mean annual air temperature and precipitation in 2015 and 2016 were $5.2{ }^{\circ} \mathrm{C}$ and $671 \mathrm{~mm}$, respectively. We used evaporative cooling and shade cloth to control the temperature on sunny days.

The experimental soil was collected from an area near the rain shelter $\left(125^{\circ} 24^{\prime} 44.69^{\prime \prime} \mathrm{E}\right.$ and $43^{\circ} 48^{\prime} 36.49^{\prime \prime} \mathrm{N}$, an altitude of $\left.231.7 \mathrm{~m}\right)$. The physico-chemical properties of the soil $(0-20 \mathrm{~cm})$ were as follows: bulk density, $1.33 \pm 0.05 \mathrm{~g} \mathrm{~cm}^{-3}$; organic matter content, $21.85 \mathrm{~g} \mathrm{~kg}^{-1}$; total $\mathrm{N}$ content, $1.48 \mathrm{~g} \mathrm{~kg}^{-1}$; available $\mathrm{N}, 80.36 \mathrm{mg} \mathrm{kg}^{-1}$; available $\mathrm{P}, 14.82 \mathrm{mg} \mathrm{kg}^{-1}$; available $\mathrm{K}, 115.42 \mathrm{mg} \mathrm{kg}^{-1}$; initial soil pH, 6.46 (soil: water =1:2.5); soil cation exchange capacity (CEC), $23 \mathrm{cmol} \mathrm{kg}^{-1}$; and clay 
content, $20.5 \%$. The soil organic C contents were determined by the Walkley-Black method [25]. The soil total $\mathrm{N}$ contents were determined by the micro-Kjeldahl method [26]. The available $\mathrm{N}$ was determined by the alkali diffusion method. The available phosphorus was determined by sodium bicarbonate-molybdenum antimony colorimetry. The available potassium was determined by flame photometry method [25]. The soil CEC was determined by the ethylene diamine tetraacetic acid (EDTA)-ammonium salt rapid method [27]. The soil clay content was determined by the pipette method [28]. The type of tested soil was black soil, equivalent to typical Phaeozem in the World Reference Base (WRB) system [29].

\subsection{Experimental Design}

A completely randomized block design was used in this experiment with two N-level treatments (N0 and N1), three methods of separation of maize and alfalfa roots, and four replicates. The N0 treatment (control) involved no $\mathrm{N}$ fertilizer, and the $\mathrm{N} 1$ treatment $\left(10.2 \mathrm{~g} \mathrm{~N} \mathrm{pot}^{-1}\right)$ involved $\mathrm{N}$ addition with urea fertilizer ( $\mathrm{N}$ content, $46 \%$ ). The following three methods were used to separate the roots of maize and alfalfa: (1) plastic sheet separation (PSS) in which a plastic sheet (0.5 mm) was used to separate the roots and prevent the transfer of solutions and hyphae; (2) nylon net separation (NNS) in which a $30 \mu \mathrm{m}$ nylon net was used to prevent root contact but permit the transfer of solutions and hyphae; and (3) no separation (NS) in which contact between the maize and the alfalfa roots was permitted (Figure 1). To prevent root contact, each pot was cut in half, and a plastic sheet, a nylon net, or no barrier was placed between the halves. Then, the pot was reconstructed to implement the PSS, the NNS, and the NS treatments and was sealed to prevent water leakage (Figure 1). The spacing of the pots in the rain shelter was $1.2 \mathrm{~m}$. The $\mathrm{N}$ transfer in the maize/alfalfa intercropping system was evaluated in the following two experiments.
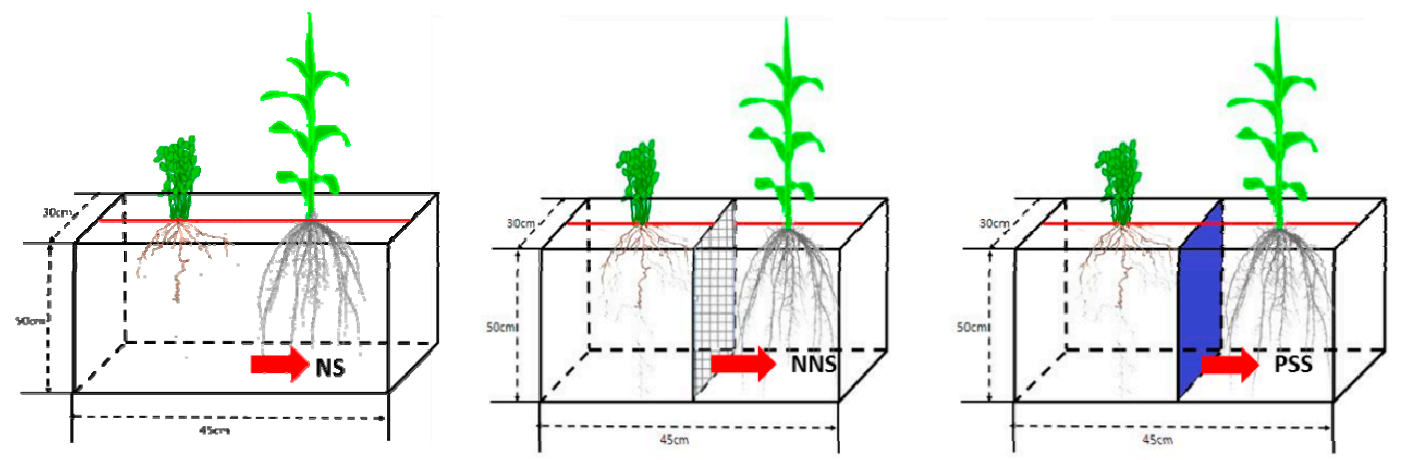

Figure 1. Schematic diagram of the maize/alfalfa intercropping pot experiment. NS represents no root separation between the maize and alfalfa, NNS and PSS represent maize and alfalfa root separation with a nylon net barrier and a plastic sheet barrier, respectively.

\subsubsection{Experiment I. Isotope $\left({ }^{15} \mathrm{~N}\right)$ Labeling of Alfalfa Leaves (Alfalfa as the ${ }^{15} \mathrm{~N}$ Donor)}

The maize and the alfalfa plants were sown together in pots (length: $45 \mathrm{~cm}$, width: $30 \mathrm{~cm}$, and height: $50 \mathrm{~cm}$ ) with $51 \mathrm{~kg}$ of soil that was passed through a $2 \mathrm{~mm}$ sieve. The application of NPK fertilizer to maize and alfalfa was conducted according to local fertilization practices [5]. Alfalfa was treated at $53 \mathrm{~kg} \mathrm{~N} \mathrm{ha}^{-1}, 135 \mathrm{~kg} \mathrm{P} \mathrm{ha}^{-1}$, and $90 \mathrm{~kg} \mathrm{~K} \mathrm{ha}^{-1}$, while $225 \mathrm{~kg} \mathrm{~N} \mathrm{ha}^{-1}, 120 \mathrm{~kg} \mathrm{P} \mathrm{ha}^{-1}$, and $60 \mathrm{~kg}^{\circ}$ $\mathrm{K} \mathrm{ha}^{-1}$ were applied to maize. The NPK fertilizer contained the following components: urea (46\% N content), superphosphate $\left(46 \% \mathrm{P}_{2} \mathrm{O}_{5}\right.$ content), and potassium oxide $\left(60 \% \mathrm{~K}_{2} \mathrm{O}\right.$ content). In addition, we calculated the fertilization amount for the pot experiment based on the fertilization amount above, and $6.12 \mathrm{~g} \mathrm{P}_{2} \mathrm{O}_{5}$ pot $^{-1}$ and $4.08 \mathrm{~g} \mathrm{~K}_{2} \mathrm{O}$ pot $^{-1}$ were applied to all pots, and $10.2 \mathrm{~g} \mathrm{~N} \mathrm{pot}^{-1}$ was applied to half of the pots and mixed thoroughly at the time of sowing of the N1 treatments (29 May 2015 and 28 May 2016). Maize and alfalfa were planted in the pots at a ratio of 1:20 for the three separation methods (1 June 2015 and 23 May 2016). Maize was planted at depth of $3 \mathrm{~cm}$ with 2-3 seeds per 
pot and thinned to one plant at the second leaf stage. The plants were watered with deionized water to maintain the soil moisture at $60-70 \%$ of the field water holding capacity throughout the growth stage, and the soil moisture in each pot was monitored by micro-tensiometers (Nanjing Institute of Soil Science, Chinese Academy of Sciences). The maize and the alfalfa seeds were sown manually to ensure that all plants were placed at the same depth. Weeds were regularly controlled with a small shovel, and maize and alfalfa pests and diseases of alfalfa or maize were controlled while attempting to minimize the effects of pesticide application on the nontarget crop.

The alfalfa leaves were labeled at the vegetative stage of the second harvest (15 August 2015 and 18 August 2016). The maize leaves were labeled simultaneously with the alfalfa leaves. The stem-associated maize was surrounded by a plastic sheet $\left(30\right.$ by $50 \mathrm{~cm}$ ) before labeling to prevent ${ }^{15} \mathrm{~N}$ contamination of the associated maize or soil from the runoff of ${ }^{15} \mathrm{~N}$-labeled solutions during foliar labeling. In addition, the surface of the pot soil was covered by two layers of plastic film and two layers of filter paper layered above the plastic film. One polyvinyl chloride cylinder $(25$ by $50 \mathrm{~cm})$ open at both ends was used to enclose the alfalfa canopy. A $1.5 \%(\mathrm{~W} / \mathrm{W})$ solution of ${ }^{15} \mathrm{~N}$-labeled urea $\left(5.14 \%{ }^{15} \mathrm{~N}\right.$ enrichment) was spread on the surface of the alfalfa leaves as described by Shen and Chu (2004). Then, the alfalfa leaves were immediately covered with white plastic bags. Once the leaf surfaces were dry, the leaves were washed three times with deionized water. In total, $10 \mathrm{~mL}$ of the ${ }^{15} \mathrm{~N}$-labeled urea solution was sprayed, and each labeling was replicated five times. The ${ }^{15} \mathrm{~N}$ labeling processes were carefully controlled to ensure that neither the soil nor the associated maize leaves were contaminated by ${ }^{15} \mathrm{~N}$. The same amount of urea solution was used as a control to determine the natural ${ }^{15} \mathrm{~N}$ abundance under the test conditions. To ensure the nodulation and the nitrogen fixation of alfalfa, a suspension of Rhizobium sp. strain ACCC177512 (supplied by the College of Resources and Environment, Jilin Agriculture University, Jilin) was applied to the alfalfa at $20 \mathrm{~mL} \mathrm{pot}^{-1}$ (density was $3.0 \times 10^{7} \mathrm{~mL}^{-1} \mathrm{CFU}$ ) at $7 \mathrm{~d}$ after sowing.

\subsubsection{Experiment II. Isotope $\left({ }^{15} \mathrm{~N}\right)$ Labeling of Maize Leaves (Maize as the ${ }^{15} \mathrm{~N}$ Donor)}

This experiment was conducted only in 2016 in the same manner as in experiment I. In this experiment, ${ }^{15} \mathrm{~N}$ was applied to the maize leaves in the same way that it was applied to the alfalfa leaves in experiment I such that maize was the donor plant, and alfalfa was the receiver plant.

\subsection{Sampling and Measurements}

On 1 October 2015 and 2016, maize and alfalfa plants under the different $\mathrm{N}$ and root-separation treatments were harvested by cutting near the soil surface. The roots were excavated and washed with running tap water. The seeds, the shoots, and the fresh roots were heated at $105^{\circ} \mathrm{C}$ for $0.5 \mathrm{~h}$ to stop all enzymatic activity, and the plants were dried at $70{ }^{\circ} \mathrm{C}$ to constant weight. The dry weights of both the maize and the alfalfa plants were measured. The total $\mathrm{N}$ contents in the plants were measured by a K-05 automatic $\mathrm{N}$ analyzer (Shanghai Sheng Sheng Automation Instrument Co., Ltd., Shanghai, China). The ${ }^{15} \mathrm{~N}$ abundance was measured by an isotope mass spectrometer (DELTA V Advantage, Thermo-Fisher Ltd., Waltham MA., USA).

\subsection{Data Calculations}

The soil $\mathrm{N}$ use efficiency of each crop $\left(\mathrm{NU}_{\mathrm{N}}\right)$ was calculated using the following equation [30]:

$$
\mathrm{NU}_{\mathrm{N}}=(\mathrm{U}-\mathrm{U} 0) / \mathrm{F} \times 100 \%,
$$

where $\mathrm{U}$ is the total amount of $\mathrm{N}$ uptake by the aboveground part of the crop after $\mathrm{N}$ application, $\mathrm{U} 0$ is the total $\mathrm{N}$ uptake in the upper part of the crop without $\mathrm{N}$ application, and $\mathrm{F}$ is the amount of applied $\mathrm{N}$ fertilizer. 
The natural ${ }^{15} \mathrm{~N}$ abundance (atom \%) in the maize and the alfalfa under the control treatments was used as the reference value. The excess ${ }^{15} \mathrm{~N}$ (atom \%) was calculated by the following equation [22]:

${ }^{15} \mathrm{~N}$ atom $\%$ excess $={ }^{15} \mathrm{~N}$ atom $\%$ excess in labeled crop $-{ }^{15} \mathrm{~N}$ atom $\%$ excess in unlabeled crop.

The ${ }^{15} \mathrm{~N}$ contents in the maize and the alfalfa plants were calculated based on the following equation:

$$
{ }^{15} \mathrm{~N} \text { content }=\left({ }^{15} \mathrm{~N} \text { atom } \% \text { excess plant } \times \text { total } \mathrm{N}_{\text {plant }}\right) /{ }^{15} \mathrm{~N} \text { atom } \% \text { excess labelled } \mathrm{N} .
$$

The $\mathrm{N}$ transfer rate $(\% \mathrm{NT})$ represents the amount of total $\mathrm{N}$ transferred from alfalfa $\left({ }^{15} \mathrm{~N}\right.$ donor plant) to maize $\left({ }^{15} \mathrm{~N}\right.$ receiver plant). The percentage of total $\mathrm{N}$ transferred from donor to receiver (\% NT) was estimated by the following equation [31]:

$$
\% \mathrm{NT}={ }^{15} \mathrm{~N} \text { content } \mathrm{receiver} \times 100 /\left({ }^{15} \mathrm{~N} \text { content } \mathrm{receiver}+{ }^{15} \mathrm{~N} \text { content } \mathrm{donor}_{\text {ror }}\right) .
$$

The amount of $\mathrm{N}\left(\mathrm{mg} \mathrm{pot}^{-1}\right)$ transferred from alfalfa was calculated as follows:

$$
\mathrm{N}_{\text {transfer }}=\% \mathrm{~N}_{\text {transfer }} \times \text { total } \mathrm{N}_{\text {donor }} /\left(100-\% \mathrm{~N}_{\text {transfer }}\right)
$$

The percentage of $\mathrm{N}$ in the receiver plant derived from the transfer (\% NDFT) was calculated according to the following equation [22]:

$$
\% \mathrm{NDFT}=\left(\mathrm{N}_{\text {transfer }} \times 100\right) / \text { total } \mathrm{N}_{\text {receiver. }}
$$

\subsection{Statistical Analysis}

The experimental data were analyzed using Microsoft Excel 2013 (Microsoft Corporation, Redmond, WA, USA), and the figures were plotted using GraphPad Prism 6.02 (GraphPad Software Inc., La Jolla, CA). The total dry biomass, the $\mathrm{N}$ content, and the ${ }^{15} \mathrm{~N}$ abundance in the maize and the alfalfa were statistically analyzed using the PROC MIXED procedure in SAS (SAS Institute, Inc., Cary, North Carolina). In the mixed model, the $\mathrm{N}$ level and the root separation method were treated as fixed factors, and the year and all interactions were considered random effects. The LSMEANS statement was used for the mean estimation of the fixed effects, and significant differences were determined with Tukey's HSD test at $\alpha=0.05$. The final model used in SAS was as follows:

$$
Y i j k l=\mu+\tau \_i+\beta \_j+\gamma \_k+\tau \beta \_i j+\tau \gamma \_i k+\beta \gamma \_j k+\tau \beta \gamma \_i j k+\delta \_l+\epsilon i j k
$$

where $\mu$ is the overall mean; $\tau_{-} i$ is the effect of the $N$ level; $\beta_{-} j$ is the effect of the root separation method; $\gamma_{-} \mathrm{k}$ is the effect of the year; $\tau \beta \_\mathrm{ij}$ is the effect of the $\mathrm{N}$ level $\times$ root separation method; $\tau \gamma_{-} i \mathrm{i}$ is the effect of the $\mathrm{N}$ level $\times$ year; $\beta \gamma_{-} \mathrm{jk}$ is the effect of the root separation method $\times$ year; $\tau \beta \gamma_{-} \mathrm{ijk}$ is the effect of the $N$ level $\times$ root separation method $\times$ year; $\delta \_l$ is the block effect; and $\in$ ijk is the error term. A linear regression analysis was conducted, and the Pearson correlation coefficients were calculated using GraphPad Prism 6.02. The multivariate ordination method was used to analyze the relationships among $\mathrm{N}$ transfer, dry biomass, and $\mathrm{N}$ uptake in maize and alfalfa.

\section{Results}

\subsection{Dry Biomass}

The total dry biomass of both the maize and the alfalfa was significantly affected by $\mathrm{N}$ level, root separation method, and year, as well as their interactions (Table 1). The total dry biomass of maize was the highest when the roots were not separated, and shoot and root dry biomasses of alfalfa were the highest when the roots were separated, regardless of when the $\mathrm{N}$ treatment was applied (Figure 2). 
On average, maize shoot and root biomasses in the N1 treatment exceeded those in the N0 treatment by $16.07 \%$ and $28.58 \%$ with no root barrier, $15.16 \%$ and $16.93 \%$ with the nylon net barrier, and $67.61 \%$ and $37.07 \%$ with the plastic sheet barrier, respectively. Under the N0 treatment, the maize shoot and root biomasses with no root barrier were $82.69 \%$ and $65.82 \%$ higher than those with the plastic sheet barrier and $63.48 \%$ and $54.47 \%$ higher than those with the nylon net barrier, respectively. Under the N1 treatment, the maize shoot and root biomasses with no root barrier were $26.51 \%$ and $55.52 \%$ higher than those with the plastic sheet barrier and $12.32 \%$ and $31.74 \%$ higher than those with the nylon net barrier, respectively. In the N1 treatment, the alfalfa shoot and root biomasses exceeded those of the N0 treatment by $10.77 \%$ and $16.72 \%$ with no root barrier, $7.05 \%$ and $11.16 \%$ with the nylon net barrier, and $3.20 \%$ and $7.68 \%$ with the plastic sheet barrier, respectively. Under the N0 treatment, the alfalfa shoot and root biomasses with the plastic sheet barrier exceeded those of the treatment with no root barrier by $77.63 \%$ and $72.55 \%$ and exceeded those with the nylon net barrier by $36.41 \%$ and $40.36 \%$. Under the N1 treatment, the alfalfa shoot and root biomasses with the plastic sheet barrier exceeded those of the treatment with no root barrier by $65.47 \%$ and $59.24 \%$ and exceeded those with the nylon net barrier by $31.81 \%$ and $33.72 \%$, respectively.
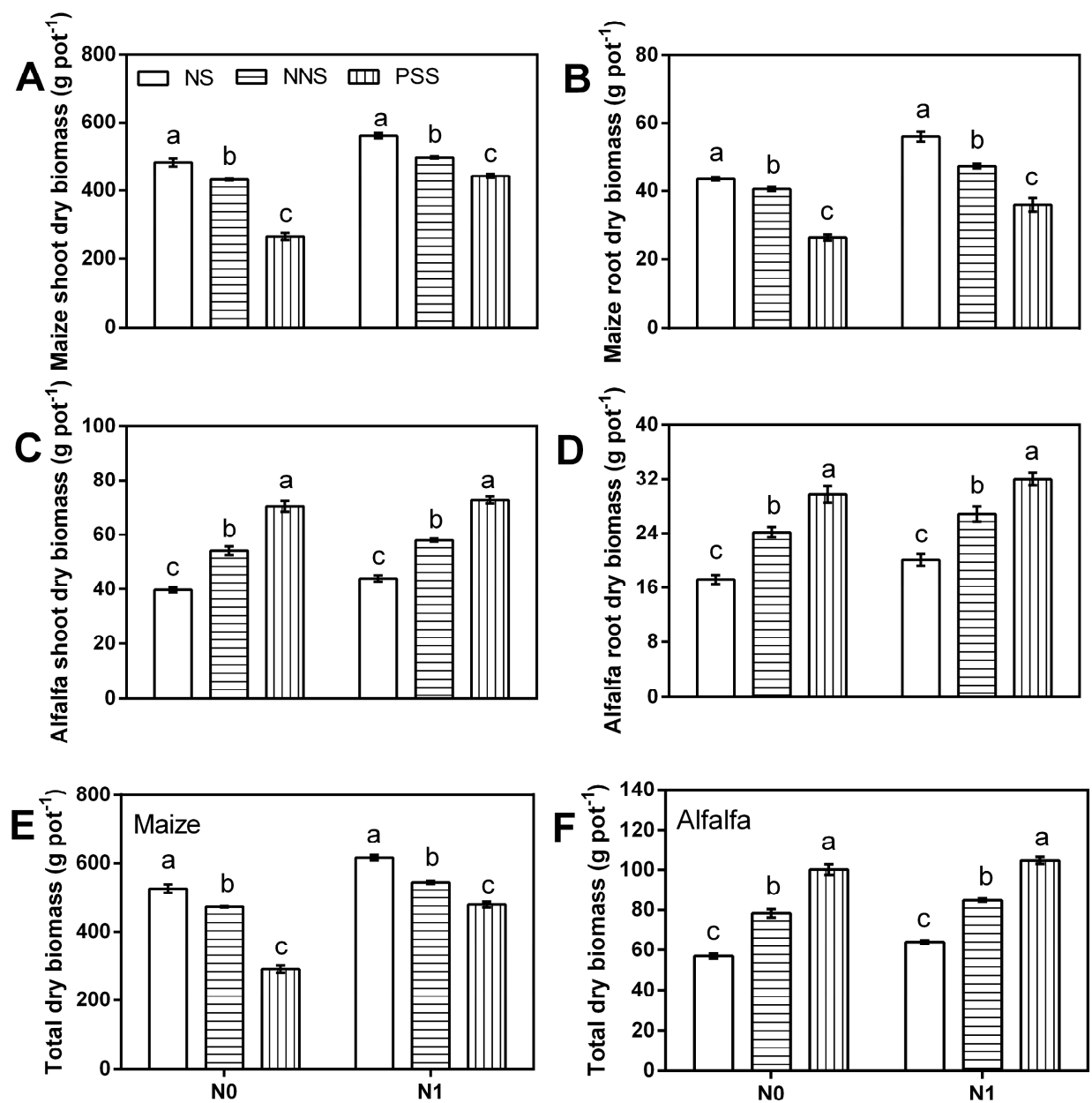

Figure 2. Effects of root separation and $\mathrm{N}$ addition on maize shoot and $\operatorname{root}(\mathbf{A}, \mathbf{B})$, alfalfa shoot and root $(\mathbf{C}, \mathbf{D})$ and total dry biomass $(\mathbf{E}, \mathbf{F})$ in 2015 and 2016. Bars are means \pm SD. Different lowercase letters indicate significant differences in maize and alfalfa dry biomass among different root separation treatments at the same nitrogen level at the $p<0.05$ probability level. N0 and N1 represent no N fertilizer addition and $\mathrm{N}$ fertilizer addition $\left(10.2 \mathrm{mg} \mathrm{N} \mathrm{pot}^{-1}\right)$. NS represents no root separation between the maize and the alfalfa, NNS and PSS represent maize and alfalfa root separation with a nylon net barrier and a plastic sheet barrier, respectively. 
Table 1. Results of the repeated measures ANOVA for the dry biomass of maize and alfalfa, with the nitrogen level $(\mathrm{N})$ and the root separation method (RS) as the independent variables and year $(\mathrm{Y})$ as the repeated measure. $x$

\begin{tabular}{cccccc}
\hline \multirow{2}{*}{ Factor } & Df & \multicolumn{2}{c}{ Maize dry Biomass $\left(\mathbf{g ~ p o t}^{-\mathbf{1}}\right)$} & \multicolumn{2}{c}{ Alfalfa Dry Biomass $\left(\mathbf{g ~ p o t}^{-\mathbf{1}}\right)$} \\
\cline { 3 - 6 } & & Shoot & Root & Shoot & Root \\
\hline $\mathrm{Y}$ & 1 & $6.43^{*}$ & $0.77 \mathrm{~ns}$ & $116.38^{* *}$ & $234.64^{* *}$ \\
$\mathrm{~N}$ & 1 & $556.16^{* *}$ & $421.09^{* *}$ & $36.40^{* *}$ & $42.69^{* *}$ \\
$\mathrm{RS}$ & 2 & $470.64^{* *}$ & $545.17^{* *}$ & $905.97^{* *}$ & $310.23^{* *}$ \\
$\mathrm{Y} \times \mathrm{N}$ & 1 & $0.00 \mathrm{~ns}$ & $4.71^{*}$ & $2.36 \mathrm{~ns}$ & $15.54^{* *}$ \\
$\mathrm{Y} \times \mathrm{RS}$ & 2 & $2.51 \mathrm{~ns}$ & $6.21^{* *}$ & $5.71^{* *}$ & $16.82^{* *}$ \\
$\mathrm{~N} \times \mathrm{RS}$ & 2 & $62.28^{* *}$ & $11.66^{* *}$ & $1.14 \mathrm{~ns}$ & $0.19 \mathrm{~ns}$ \\
$\mathrm{Y} \times \mathrm{N} \times \mathrm{RS}$ & 4 & $2.15 \mathrm{~ns}$ & $10.50^{* *}$ & $1.24 \mathrm{~ns}$ & $0.86 \mathrm{~ns}$ \\
\hline
\end{tabular}

Analysis of variance (ANOVA) $p$ values and symbols are defined as: ${ }^{*} p<0.05 ;{ }^{* *} p<0.01$; NS: $p>0.05$.

\subsection{N Uptake}

The total $\mathrm{N}$ uptake of both the maize and the alfalfa was significantly affected by $\mathrm{N}$ level, root separation method, and planting year, as well as their interactions (Table 2). The total $\mathrm{N}$ uptake of maize was the highest when the roots were not separated, and the $\mathrm{N}$ uptake in the alfalfa plants' shoots and roots was the highest when the roots were separated, regardless of the $\mathrm{N}$ level applied (Figure 3). On average, in the N1 treatment, the N uptake in the maize shoots and roots exceeded that in the N0 treatment by $25.71 \%$ with no root barrier, by $82.53 \%$, and $66.84 \%$ with the nylon net barrier, and by $139.41 \%$ and $134.38 \%$ with the plastic sheet barrier, respectively. Under the N0 treatment, the $\mathrm{N}$ uptake in the maize shoots and roots with no root barrier exceeded that with the plastic sheet barrier by $112.90 \%$ and $215.93 \%$ and exceeded that with the nylon net barrier by $92.55 \%$ and $101.32 \%$. Under the N1 treatment, the N uptake in the maize shoots and roots with no root barrier exceeded that with the plastic sheet barrier by $72.78 \%$ and $65.49 \%$ and exceeded that with the nylon net barrier by $47.22 \%$ and $39.95 \%$, respectively. The $\mathrm{N}$ uptake in the alfalfa shoots and roots exceeded that of the N0 treatment by $20.58 \%, 25.28 \%$ with no root barrier, $9.35 \%$ and $21.49 \%$ with the nylon net barrier, and $17.78 \%$ and $18.14 \%$ with the plastic sheet barrier under the N1 treatment. Under the N0 treatment, the $\mathrm{N}$ uptake in the alfalfa shoots and roots with the plastic sheet barrier exceeded that with no root barrier by $61.77 \%$ and $66.51 \%$ and exceeded that with the nylon net barrier by $38.31 \%$ and $37.12 \%$. Under the $\mathrm{N} 1$ treatment, the $\mathrm{N}$ uptake in the alfalfa shoots and roots with the plastic sheet barrier exceeded that with no root barrier by $59.01 \%$ and $56.37 \%$ and exceeded that with the nylon net barrier by $26.21 \%$ and $32.41 \%$, respectively.

Table 2. Results of repeated measures ANOVA for the nitrogen uptake of maize and alfalfa, with nitrogen level (N) and root separation method (RS) as the independent variables and year $(\mathrm{Y})$ as the repeated measure.

\begin{tabular}{cccccc}
\hline \multirow{2}{*}{ Factors } & Df & \multicolumn{2}{c}{ Maize nitrogen Uptake $\left(\mathbf{g ~ p o t}^{-\mathbf{1}}\right)$} & \multicolumn{2}{c}{ Alfalfa Nitrogen Uptake $\left(\mathbf{g ~ p o t}^{-\mathbf{1}}\right)$} \\
\cline { 3 - 6 } & & Shoot & Root & Shoot & Root \\
\hline $\mathrm{Y}$ & 1 & $33.63^{* *}$ & $2.09 \mathrm{~ns}$ & $450.14^{* *}$ & $101.10^{* *}$ \\
$\mathrm{~N}$ & 1 & $4444.12^{* *}$ & $544.04^{* *}$ & $153.68^{* *}$ & $67.15^{* *}$ \\
$\mathrm{RS}$ & 2 & $1044.18^{* *}$ & $286.31^{* *}$ & $613.31^{* *}$ & $408.66^{* *}$ \\
$\mathrm{Y} \times \mathrm{N}$ & 1 & $10.86^{* *}$ & $43.58^{* *}$ & $0.48 \mathrm{~ns}$ & $54.72^{* *}$ \\
$\mathrm{Y} \times \mathrm{RS}$ & 2 & $0.27 \mathrm{~ns}$ & $3.81^{*}$ & $17.24^{* *}$ & $2.63 \mathrm{~ns}$ \\
$\mathrm{~N} \times \mathrm{RS}$ & 2 & $36.38^{* *}$ & $7.42^{* *}$ & $6.46^{* *}$ & $11.81^{* *}$ \\
$\mathrm{Y} \times \mathrm{N} \times \mathrm{RS}$ & 4 & $0.89 \mathrm{~ns}$ & $14.56^{* *}$ & $0.50 \mathrm{~ns}$ & $25.63^{* *}$ \\
\hline
\end{tabular}

Analysis of variance (ANOVA) $p$ values and symbols are defined as: ${ }^{*} p<0.05$; ${ }^{* *} p<0.01$; NS: $p>0.05$. The other symbols are the same as for Table 1. 

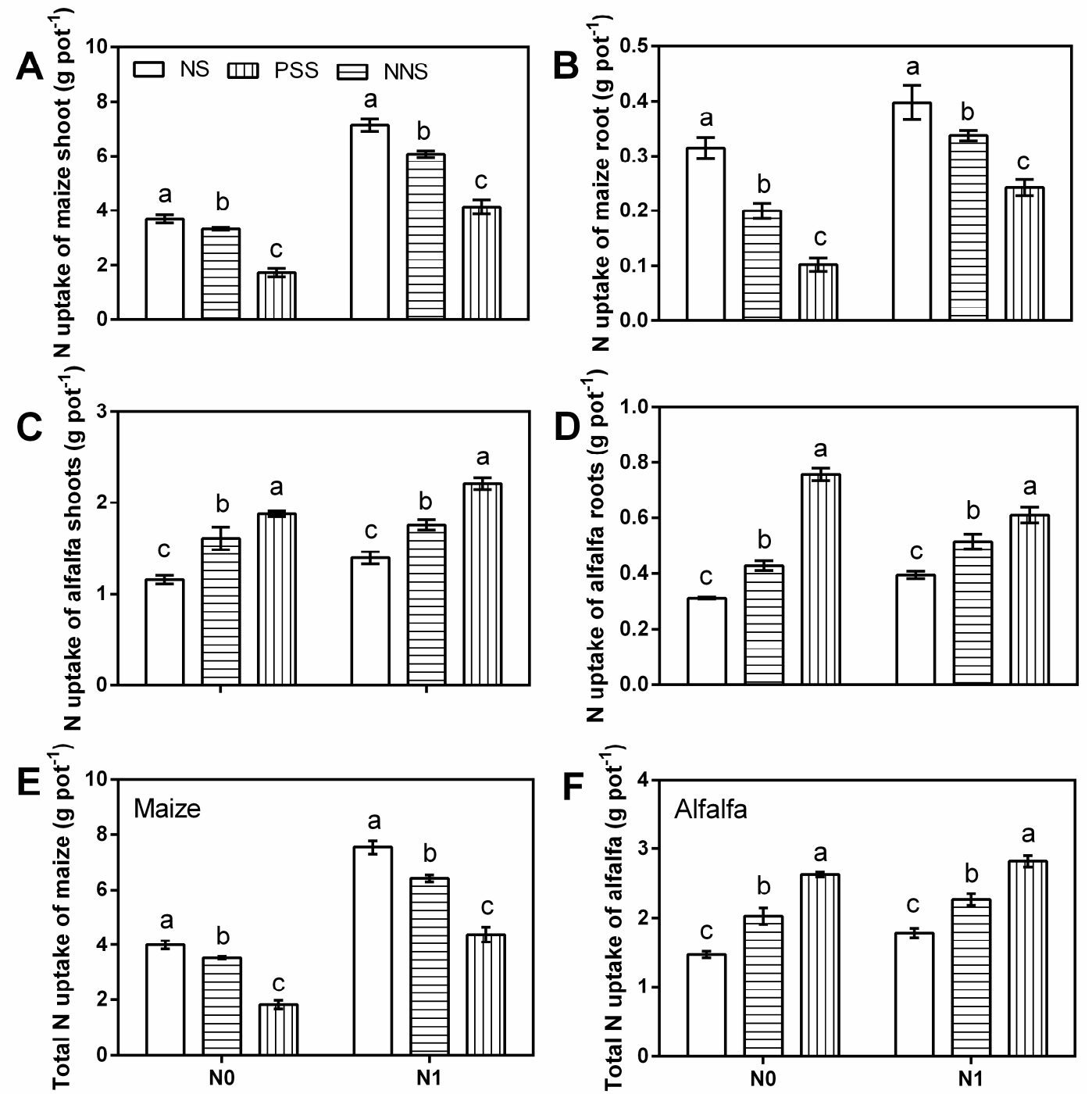

Figure 3. Effects of root separation and $\mathrm{N}$ addition on maize $(\mathbf{A}, \mathbf{B})$, alfalfa $(\mathbf{C}, \mathbf{D})$, and total $\mathrm{N}$ uptake $(\mathbf{E}, \mathbf{F})$ in 2015 and 2016. Bars are means \pm SD. Different lowercase letters indicate significant differences in maize and alfalfa $\mathrm{N}$ uptake among different root separation treatments at the same nitrogen level at the $p<0.05$ probability level. Other symbols are the same as in Figure 2.

\section{3. ${ }^{15} \mathrm{~N}$ Abundance}

When alfalfa as ${ }^{15} \mathrm{~N}$-donor plant in 2015 and 2016, the ${ }^{15} \mathrm{~N}$ abundance in the shoots of maize only was significantly affected by the root separation method. The ${ }^{15} \mathrm{~N}$ abundance in the roots of maize was significantly affected by $\mathrm{N}$ levels, root separation method, and their interactions (except that the interactions among the year, the $\mathrm{N}$ levels, and the root separation method were not significant). The ${ }^{15} \mathrm{~N}$ abundance in the shoots of alfalfa was significantly affected by the year, the interactions between year and $\mathrm{N}$ levels, and the interactions between year and root separation method; in the roots, it was significantly affected by year, $\mathrm{N}$ levels, and root separation method, as well as their respective interactions (Table 3). On average, under the N0 treatment, the ${ }^{15} \mathrm{~N}$ abundances in maize and alfalfa shoots and roots were $0.387 \%, 0.392 \%, 0.773 \%$, and $0.516 \%$ with no root barrier, $0.387 \%, 0.391 \%, 0.798 \%$, and $0.512 \%$ with a nylon net barrier, and $0.372 \%, 0.372 \%, 0.731 \%$, and $0.520 \%$ with a plastic sheet barrier, respectively. Under the $\mathrm{N} 1$ treatment, the ${ }^{15} \mathrm{~N}$ abundances in maize and alfalfa shoots and roots were $0.387 \%, 0.390 \%, 0.789 \%$, and $0.511 \%$ with no root barrier, $0.383 \%, 0.382 \%, 0.796 \%$, and $0.565 \%$ with a nylon net barrier, $0.372 \%, 0.371 \%, 0.774 \%$, and $0.544 \%$ with a plastic sheet barrier, respectively (Table 4). 
When maize as ${ }^{15} \mathrm{~N}$-donor plant, the ${ }^{15} \mathrm{~N}$ abundances in shoots and roots of alfalfa were significantly affected by the $\mathrm{N}$ levels but were not significant affected by the root separation method and the interaction between $\mathrm{N}$ levels and root separation method (Table 3). Under the $\mathrm{N} 0$ treatment, the ${ }^{15} \mathrm{~N}$ abundances in the alfalfa shoots and roots were $0.369 \%$ and $0.368 \%$ with no root barrier, $0.370 \%$ and $0.369 \%$ with a nylon net barrier, and $0.369 \%$ and $0.369 \%$ with a plastic sheet barrier, respectively. Under the N1 treatment, the ${ }^{15} \mathrm{~N}$ abundance in the alfalfa shoot and root was $0.368 \%$ and $0.368 \%$ with no root barrier, $0.368 \%$ and $0.367 \%$ with a nylon net barrier, $0.369 \%$ and $0.368 \%$ with a plastic sheet barrier, respectively (Table 4).

Table 3. Results of the repeated measures ANOVA for shoot and $\operatorname{root}{ }^{15} \mathrm{~N}$ abundance of maize and alfalfa, with nitrogen level (N) and root separation method (RS) as the independent variables and year $(\mathrm{Y})$ as the repeated measure.

\begin{tabular}{|c|c|c|c|c|c|c|c|}
\hline \multirow[b]{2}{*}{ Factors } & \multirow[b]{2}{*}{ Df } & \multicolumn{4}{|c|}{${ }^{15} \mathrm{~N}$ Abundance (Alfalfa as ${ }^{15} \mathrm{~N}$-donor Plant) } & \multicolumn{2}{|c|}{${ }^{15} \mathrm{~N}$ Abundance (Maize as ${ }^{15} \mathrm{~N}$-donor Plant) } \\
\hline & & $\begin{array}{l}\text { Maize } \\
\text { Shoot }\end{array}$ & $\begin{array}{c}\text { Maize } \\
\text { Root }\end{array}$ & $\begin{array}{l}\text { Alfalfa } \\
\text { Shoot }\end{array}$ & $\begin{array}{c}\text { Alfalfa } \\
\text { Root }\end{array}$ & Alfalfa Shoot & Alfalfa Root \\
\hline $\mathrm{Y}$ & 1 & $0.26 \mathrm{~ns}$ & $3.69 \mathrm{~ns}$ & $68.27^{* *}$ & $374.08^{* *}$ & & \\
\hline $\mathrm{N}$ & 1 & $0.68 \mathrm{~ns}$ & $26.42 * *$ & $1.30 \mathrm{~ns}$ & $13.58^{* *}$ & $6.94 *$ & $24.14^{* *}$ \\
\hline RS & 2 & $47.13^{* *}$ & $221.05^{* *}$ & $2.44 \mathrm{~ns}$ & $5.16^{*}$ & $1.63 \mathrm{~ns}$ & $2.71 \mathrm{~ns}$ \\
\hline $\mathrm{Y} \times \mathrm{N}$ & 1 & $2.50 \mathrm{~ns}$ & $13.59 * *$ & $8.09 * *$ & $5.94 *$ & & \\
\hline $\mathrm{Y} \times \mathrm{RS}$ & 2 & $3.00 \mathrm{~ns}$ & $12.73 * *$ & $4.94 *$ & $5.20 *$ & & \\
\hline $\mathrm{N} \times \mathrm{RS}$ & 2 & $1.18 \mathrm{~ns}$ & $9.47^{* *}$ & $0.63 \mathrm{~ns}$ & $6.68^{* *}$ & $3.34 \mathrm{~ns}$ & $1.86 \mathrm{~ns}$ \\
\hline $\mathrm{Y} \times \mathrm{N} \times \mathrm{RS}$ & 4 & $2.11 \mathrm{~ns}$ & $1.73 \mathrm{~ns}$ & $1.68 \mathrm{~ns}$ & $3.35 *$ & & \\
\hline
\end{tabular}

Values are the means. Analysis of variance (ANOVA) $p$ values and symbols are defined as follows: ${ }^{*} p<0.05$; ** $p<0.01$; and NS: $p>0.05$. The other symbols are the same as in Table 1 .

Table 4. ${ }^{15} \mathrm{~N}$ abundance (\%) in shoots and roots of maize and alfalfa under different conditions.

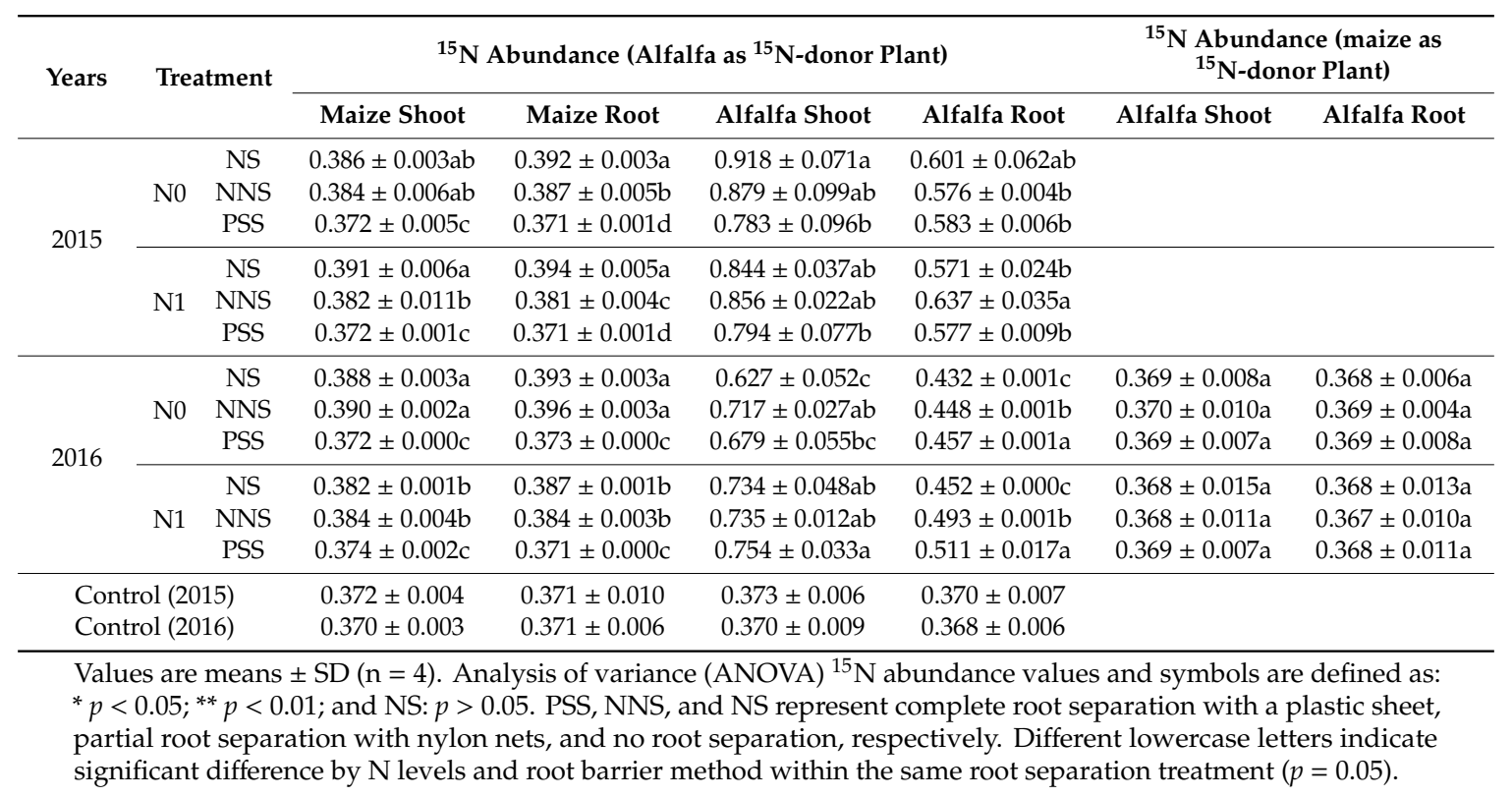

\subsection{N Transfer}

The $\mathrm{N}$ transfer rate and amount were significantly affected by $\mathrm{N}$ level, root separation pattern, and year (Table 5). Under the N0 treatment, the rate and the amount of $\mathrm{N}$ transfer from alfalfa to maize was $15.05 \%$ and $204.56 \mathrm{mg} \mathrm{pot}^{-1}$ with no root barrier and $9.30 \%$ and $165.12 \mathrm{mg}^{-1}$ with a nylon net barrier (Table 5). The $\mathrm{N}$ transfer accounted for $4.72 \%$ and $10.81 \%$ of the total $\mathrm{N}$ that accumulated in maize and alfalfa with no root barrier and $4.48 \%$ and $6.86 \%$ of that accumulated in maize and alfalfa with a nylon net barrier, respectively. Under the N1 treatment, the rate and the amount of N transfer from alfalfa to maize was $12.47 \%$ and $197.70 \mathrm{mg} \mathrm{pot}^{-1}$ with no root barrier and $7.02 \%$ and $139.04 \mathrm{mg}$ 
pot $^{-1}$ with a nylon net barrier in 2015 and 2016. The $\mathrm{N}$ transfer accounted for $3.64 \%$ and $13.32 \%$ of the total $\mathrm{N}$ that accumulated in maize and alfalfa with no root barrier and $2.36 \%$ and $5.86 \%$ of that accumulated in maize and alfalfa with a nylon net barrier, respectively. However, there was no $\mathrm{N}$ transfer in the plastic sheet separation (PSS) treatment since the plastic sheet $(0.5 \mathrm{~mm})$ was used to completely separate the roots and the soil.

Table 5. Nitrogen transferred from ${ }^{15} \mathrm{~N}$-labeled plants to intercropped plants under different experimental conditions.

\begin{tabular}{|c|c|c|c|c|c|c|}
\hline Years & Trea & ment & $\begin{array}{c}\text { Rate of N } \\
\text { Transferred (\%) }\end{array}$ & $\begin{array}{c}\text { Amount of } \mathbf{N} \\
\text { Transferred (mg pot } \\
-1 \text { ) }\end{array}$ & $\begin{array}{l}\text { N Transferred as } \\
\text { of Maize N (\%) }\end{array}$ & $\begin{array}{l}\text { N Transferred as } \\
\text { of Alfalfa N (\%) }\end{array}$ \\
\hline \multirow{4}{*}{2015} & \multirow{2}{*}{ No } & NS & $14.52 \pm 1.01 a$ & $167.92 \pm 13.82 \mathrm{a}$ & $3.53 \pm 0.40 \mathrm{a}$ & $8.93 \pm 0.12 a$ \\
\hline & & NNS & $7.48 \pm 2.06 \mathrm{~b}$ & $119.89 \pm 34.31 b$ & $3.18 \pm 0.43 a$ & $5.09 \pm 0.32 b$ \\
\hline & \multirow{2}{*}{ N1 } & NS & $11.86 \pm 1.48 a$ & $165.83 \pm 25.60 a$ & $4.41 \pm 0.26 a$ & $16.55 \pm 0.45 a$ \\
\hline & & NNS & $5.14 \pm 0.14 b$ & $90.40 \pm 1.99 b$ & $1.96 \pm 1.04 \mathrm{~b}$ & $4.89 \pm 0.36 b$ \\
\hline \multirow{4}{*}{2016} & \multirow{2}{*}{ N0 } & NS & $15.58 \pm 2.29 a$ & $241.19 \pm 30.45 a$ & $5.90 \pm 0.64 a$ & $12.69 \pm 1.85 a$ \\
\hline & & NNS & $11.12 \pm 1.30 \mathrm{~b}$ & $210.36 \pm 27.94 a$ & $5.78 \pm 0.65 a$ & $8.62 \pm 1.07 \mathrm{~b}$ \\
\hline & \multirow{2}{*}{ N1 } & NS & $13.07 \pm 1.00 \mathrm{a}$ & $229.56 \pm 8.32 a$ & $2.87 \pm 0.12 a$ & $10.09 \pm 0.68 \mathrm{a}$ \\
\hline & & NNS & $8.89 \pm 0.39 b$ & $187.67 \pm 4.17 \mathrm{~b}$ & $2.75 \pm 0.08 \mathrm{a}$ & $6.82 \pm 0.24 b$ \\
\hline \multirow{4}{*}{$\begin{array}{l}2 \text { year } \\
\text { average }\end{array}$} & \multirow{2}{*}{ No } & NS & $15.05 \pm 1.51 \mathrm{a}$ & $204.56 \pm 18.79 a$ & $4.72 \pm 0.42 a$ & $10.81 \pm 1.42 \mathrm{a}$ \\
\hline & & NNS & $9.30 \pm 0.71 b$ & $165.12 \pm 15.97 b$ & $4.48 \pm 0.22 a$ & $6.86 \pm 0.33 b$ \\
\hline & \multirow{2}{*}{ N1 } & NS & $12.47 \pm 0.93 a$ & $197.70 \pm 12.76 a$ & $3.64 \pm 0.26 a$ & $13.32 \pm 0.77 a$ \\
\hline & & NNS & $7.02 \pm 1.70 b$ & $139.04 \pm 11.97 \mathrm{~b}$ & $2.36 \pm 0.60 \mathrm{~b}$ & $5.86 \pm 1.50 \mathrm{~b}$ \\
\hline
\end{tabular}

The data represent the means of four replicates; values followed by different letters in the same column are significantly different at the $p<0.05$ probability level. The other symbols are the same as in Table 4 .

\subsection{Correlation Analysis}

The maize biomass (2015: $\left.\mathrm{r}^{2}=0.5649, p<0.0001,2016: \mathrm{r}^{2}=0.5696, p<0.0001\right)$, the $\mathrm{N}$ uptake (2015: $\left.\mathrm{r}^{2}=0.5572, p<0.0001,2016: \mathrm{r}^{2}=0.2508, p=0.0127\right)$, and the $\mathrm{N}$ utilization $\left(2015: \mathrm{r}^{2}=0.6361\right.$, $\left.p=0.0019,2016: \mathrm{r}^{2}=0.3584, p=0.0397\right)$ were significantly and positively correlated with the amount of $\mathrm{N}$ transferred in the system between maize and alfalfa (Figure $4 \mathrm{~A}, \mathrm{C}, \mathrm{E}$ ). However, the alfalfa biomass (2015: $\left.\mathrm{r}^{2}=0.5726, p<0.0001,2016: \mathrm{r}^{2}=0.8407, p<0.0001\right)$, the $\mathrm{N}$ uptake $\left(2015: \mathrm{r}^{2}=0.4234, p=0.0006\right.$, 2016: $\left.\mathrm{r}^{2}=0.7907, p<0.0001\right)$, and the $\mathrm{N}$ utilization (2016: $\mathrm{r}^{2}=0.4370, p=0.0134$ ) were negatively correlated with the amount of $N$ transferred (Figure 4B,D,F). 

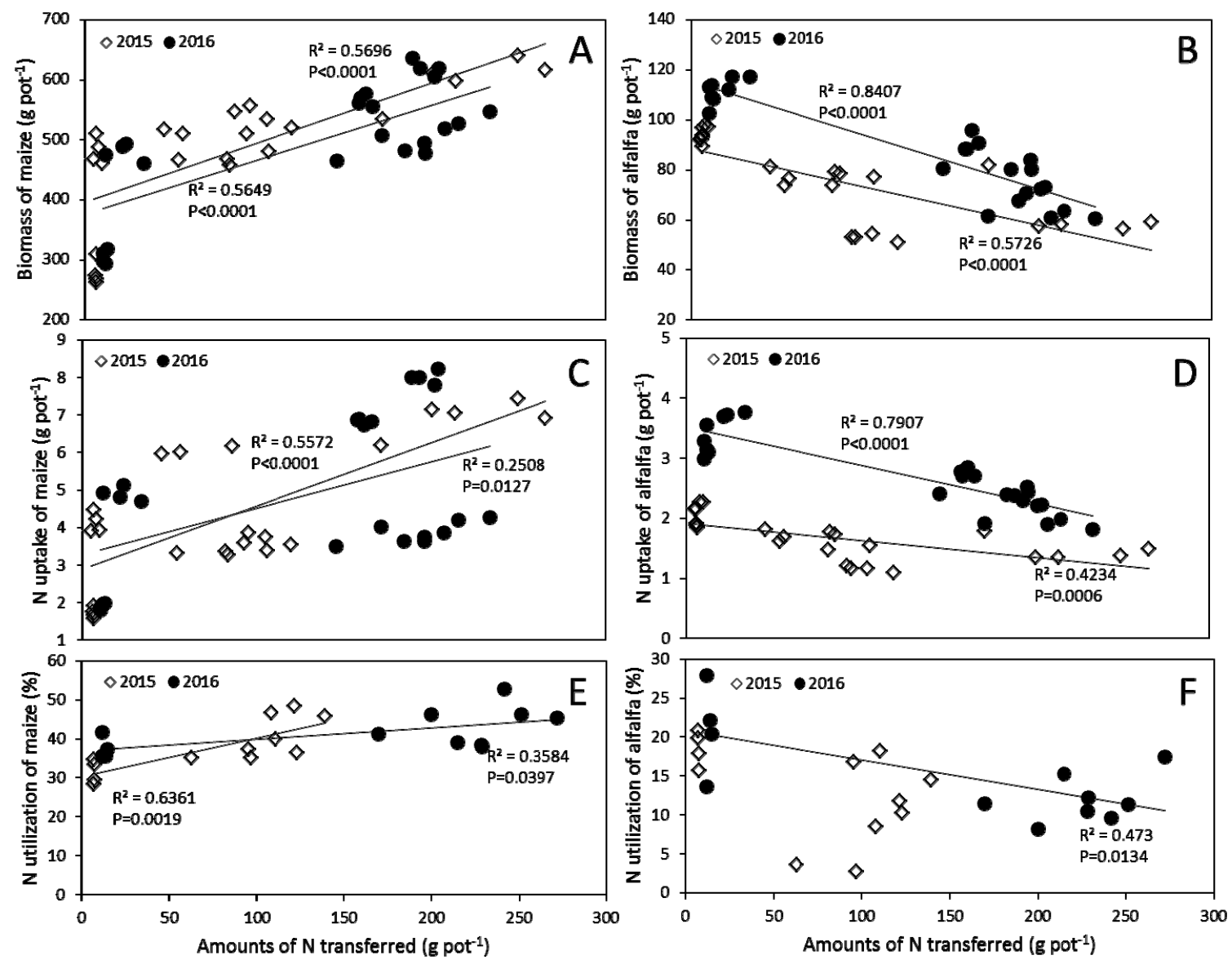

Figure 4. Correlations between $\mathrm{N}$ transfer and biomass and between $\mathrm{N}$ uptake and $\mathrm{N}$ utilization of maize (A,C,E) and alfalfa (B,D,F) in 2015 and 2016.

\section{Discussion}

\subsection{Crop Biomass and N Uptake in the Intercropping System of Maize and Alfalfa}

Previous studies found that root interactions generate yield advantages in different legume-cereal intercropping systems, e.g., peanut/rice, faba bean/wheat, and faba bean/maize intercropping systems $[7,32,33]$. Consistent with these studies, our data indicated that maize with no root barrier had the highest biomass. However, the opposite was true for alfalfa, in which greater biomass was achieved with the nylon net or plastic separation than with no root separation (Figure 2). In our experiment, we also found that the average values of aggressivity of maize relative to alfalfa (Ama) in the two year experiment were higher than one in all treatments. The $\mathrm{N}$ competitive ratio of maize relative to alfalfa (NCRma) values were also higher than one in each treatment in 2015 and 2016 (Table A1). Therefore, the competitiveness of maize was greater than that of alfalfa in the maize/alfalfa intercropping system, and the increased biomass in the maize/alfalfa intercropping was attributed to the significant increase in maize biomass, which is consistent with previous field trial studies $[5,20]$. The maize biomass was $32.37 \%$ higher with a nylon net barrier than with a plastic sheet barrier, which could be related to mycorrhizae and hyphae $[8,31]$ or to the movement of water and nutrients from the alfalfa side of the pots in response to the much higher demands of the maize. In addition, the maize biomass with no root barrier was $48.69 \%$ higher than that with a plastic sheet barrier and $12 \%$ higher than that with a nylon net barrier, which could be due to the extra $\mathrm{N}$ from the alfalfa side, the other nutrients, or the soil that was available. Therefore, our data demonstrated that root contact stimulated the growth of non-legumes in a maize/alfalfa intercropping system. However, the alfalfa biomass was reduced by $40.94 \%$ with no root barrier compared with that under the plastic sheet barrier treatment and by $19.76 \%$ 
compared with that under the nylon net barrier treatment. This finding may be due to the maize plants being taller than the alfalfa plants in the intercropping system (under the N0 treatment, the plant heights of maize and alfalfa were $238.93 \mathrm{~cm}$ and $78.14 \mathrm{~cm}$, respectively. Under N1 treatment, the plant heights of maize and alfalfa were $250.62 \mathrm{~cm}$ and $69.53 \mathrm{~cm}$, respectively), which limited the growth of alfalfa because of a shading effect [34] (Figure A1). The significant difference between 2015 and 2016 may be related to the low atmospheric temperature from July to September 2015 (Tables 1 and 2, Figure A2), which affected the growth of maize during the tassel initiation and silking stages $[5,20]$. Although water shortages are a key factor limiting crop growth and nutrient availability $[35,36]$, in our pot experiment, sufficient water was applied throughout the growth period; therefore, water was not a limiting factor for plant growth.

Based on the averages of 2015 and 2016, under the N0 treatment, the whole plant N concentration for maize and alfalfa was $0.59 \%$ and $2.68 \%$, respectively. Under N1 treatment, the whole plant $\mathrm{N}$ concentration for maize and alfalfa was $0.99 \%$ and $2.85 \%$, respectively. Several studies have shown that intercropping can increase $\mathrm{N}$ uptake and utilization through niche complementarity and facilitation processes $[8,21,33]$. Consistent with these studies, our data indicated that root contact enhanced the $\mathrm{N}$ uptake of intercropped maize; a significant increase was observed, especially under low $\mathrm{N}$ conditions, indicating that root interaction was more conducive to the acquisition of plant nutrients under nutrient stress (Figure 3). In addition, the higher biomass and $\mathrm{N}$ uptake in maize than in alfalfa indicated that maize was more competitive for $\mathrm{N}$ than alfalfa; the root system of maize grew faster and wider than that of alfalfa (maize root length density: $1.41-2.14 \mathrm{~cm} \mathrm{~cm}^{-3}$; alfalfa root length density: $0.07-0.12 \mathrm{~cm} \mathrm{~cm}^{-3}$ ).

\subsection{N Transfer between Maize and Alfalfa}

The transfer of $\mathrm{N}$ from legumes to cereal plants by root interactions is an important strategy for the improvement of $\mathrm{N}$ utilization in intercropping systems. Previous studies have found that $\mathrm{N}$ transfer occurs in most cereal/legume intercropping systems and that the $\mathrm{N}$ transfer rates range from 3.1\% to $15 \%[7,21]$. Consistent with these findings, the ${ }^{15} \mathrm{~N}$ foliar feeding results clearly showed that the transfer rate was $7.02-15.05 \%$, which falls well within an acceptable range (Table 5). Three important and distinct pathways of $\mathrm{N}$ transfer from legumes to non-legumes are (1) decomposition of legume root tissues; (2) root exudation; and (3) mycorrhizae [31,37]. Although root decomposition plays an important role in $\mathrm{N}$ transfer, it is generally a slow process [37]. Therefore, the root decomposition pathway may not contribute greatly to short-term $\mathrm{N}$ transfer. In our study, the amount of $\mathrm{N}$ transferred from alfalfa to maize under the nylon net barrier treatment was $165.13 \mathrm{mg} \mathrm{pot}^{-1}$. This amount may have been mainly transferred through the root exudation or the mycorrhizal pathways in response to the much higher $\mathrm{N}$ demand by the maize, since the maize and the alfalfa roots were not in direct contact. In addition, the amount of $\mathrm{N}$ transferred without a root barrier was 1.24-1.42 times higher than that with a nylon net barrier regardless of the $\mathrm{N}$ level applied (Table 5). The main reason for the high nitrogen transfer with no $\mathrm{N}$ barrier may be that the close root contact of maize and alfalfa can stimulate the plants to release more $\mathrm{N}$-containing compounds or generate more mycelial connections between the legume and the cereal plants [21]. Moreover, root contact reduces the travel distance of $\mathrm{N}$ compounds through mass flow [31], which efficiently promotes $\mathrm{N}$ transfer in soybean/maize intercropping systems [14]. In addition, root morphology and biomass influence the uptake and the utilization of soil water and nutrients and permit subsequent $\mathrm{N}$ transfers between cereals and legumes [23]. The maize root length density and root biomass with no root barrier were significantly higher than those with the nylon net barrier (data not shown). The higher maize root length density and root biomass with no root barrier may have facilitated the acquisition of $\mathrm{N}$ compounds from alfalfa. Overall, the $\mathrm{N}$ transfer contributed $3.64-4.72 \%$ of the total maize $\mathrm{N}$ uptake with no root barrier and $2.36-4.48 \%$ of the total maize $\mathrm{N}$ uptake with the nylon net barrier (Figure 4), demonstrating that $\mathrm{N}$ transfer from alfalfa to maize improves the $\mathrm{N}$ uptake and the $\mathrm{N}$ utilization in an alfalfa/maize intercropping system. Consistent with previous studies [38-40], we found that $\mathrm{N}$ addition significantly restricted $\mathrm{N}$ transfer (Table 5), which may be related to the greater likelihood of maize using $\mathrm{N}$ from soil 
and fertilizer than biologically fixed $\mathrm{N}$ from alfalfa in $\mathrm{N}$-rich soils $[7,22,41]$.Our other research data also proved this problem regarding the effect of different nitrogen application levels and root separation methods on nitrogen fixation ability of alfalfa in a maize/alfalfa intercropping system (Tables A2 and A3, Figures A3 and A4).

Overall, the maize/alfalfa intercropping system has the potential to improve total biomass and $\mathrm{N}$ uptake compared to monoculture. This result is consistent with many other studies and demonstrates the advantages of intercropping [5,42]. In addition, the total biomass and the $\mathrm{N}$ uptake with no root barrier were significantly higher than those with the nylon net barrier. In conclusion, the root contact plays an important role in intercropping [14]. However, the maize/alfalfa intercropping system has no commercial applicability. This is mainly due to the following reasons. First, with the increase of China's maize storage and market competition after China's accession to the WTO, the farmers' enthusiasm for agricultural production has severely reduced since the price of maize fell sharply in 2016 [43]. Second, the key limiting factor for large-scale production of intercropping is the mechanization of intercropping [44]. This problem is becoming more and more acute due to rising labor costs and the gradual intensification of rural labor shortages. To realize the mechanization of intercropping production, on the one hand, it requires agronomically standardized, high-yield, and efficient inter-species arrangement patterns and row spacing arrangements; on the other hand, it has corresponding sowing, fertilizer application, and harvest machinery. Obviously, compared to a monoculture system, the management intercropping system is more complicated and inconvenient. In order to simplify the management of this intercropping system, it will be necessary to integrate multidisciplinary knowledge to develop efficient machinery. Third, the crop combination and the proper variety selection in intercropping are the keys to success, but little attention has been paid to this. Appropriate crop species or variety combinations can enhance positive interspecific interactions between crops, reduce competition between crops, and increase productivity. Therefore, it is a problem worthy of attention to breed crops with certain crop characteristics that are conducive to inter-species promotion and reduce competition [45].

Finally, further research is required to assess the long-term benefits of the composite crop population and its responses to rainfall, planting years, and environmental stresses (pest, disease, and freezing injury) in order to avoid agronomic risks and economic loss. Therefore, the dissemination of efficient intercropping technologies and expert technical guidance as well as financial support of government will necessarily play important roles in putting alfalfa/maize intercropping into practice in agricultural and pastoral areas in Northeast China [5].

\section{Conclusions}

The two year pot experiments demonstrated that $\mathrm{N}$ transfer between the two plants occurred mainly from alfalfa to maize. The $\mathrm{N}$ transfer rate was $7.02-15.05 \%$, which accounted for $2.36-4.72 \%$ of the total $\mathrm{N}$ uptake. Root contact can improve $\mathrm{N}$ transfer, which can increase total biomass, total $\mathrm{N}$ uptake, and $\mathrm{N}$ utilization in maize. Our results highlight the importance and the relevance of root contact for increasing of $\mathrm{N}$ transfer and utilization in maize/alfalfa intercropping systems. Maize/alfalfa intercropping has obvious advantages in terms of crop biomass and $\mathrm{N}$ uptake, which can ensure food security and provide superior forage. In addition, $\mathrm{N}$ fixation and transfer from alfalfa to maize can improve soil fertility and reduce chemical fertilizer application. In conclusion, the promotion and the application of maize/alfalfa are determined as the optimal strategy, which will be beneficial to further development for intercropping.

Author Contributions: The experiment was conceived and designed by Y.G. and Q.G. The data from the experiments were collected by Z.S., X.W. and H.Z. and analyzed by Z.S., H.Y., Y.W., J.Z. and J.N. The reagents, chemicals, materials, and analysis tools were contributed by Q.G. and Y.G. The paper was written by Z.S. and X.W. and modified by Y.G. All authors have read and agreed to the published version of the manuscript. 
Funding: This study was financially supported by the National Natural Science Foundation $(31471945 ; 31670446$; U1803110), the Jilin Provincial Science and Technology Department Natural Science Foundation (20180101126JC), the National Key R\&D Program of China-Investigating Mechanism on Leaching, Loss, Pollution and Control of N and P in Agroecosystems (2016YFD0800103), the Jilin Provincial Science and Technology Department (201801011), and the Jilin Special Program for Key Science and Technology Research (Y8D1161001).

Acknowledgments: We would like to thank Juntao Cui of the Department of Environmental Sciences for providing the Rhizobium strain ACCC177512.

Conflicts of Interest: This manuscript has no financial or non-financial competing interests.

\section{Appendix A}

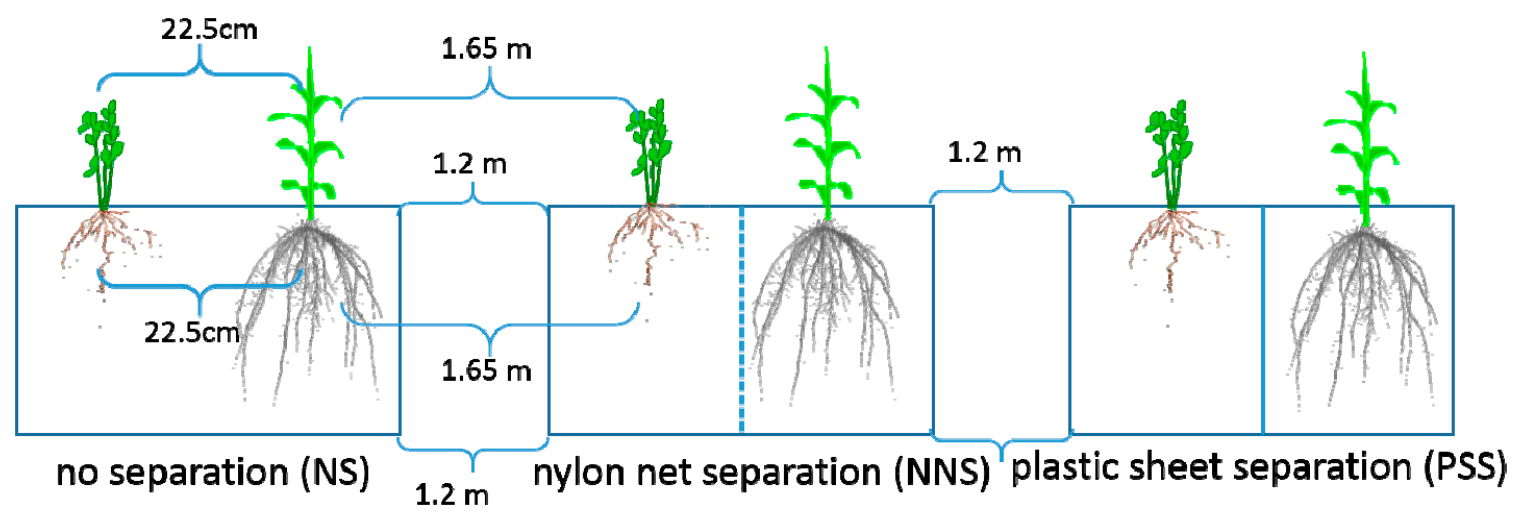

Figure A1. Schematic diagram of the maize/alfalfa intercropping pot experiment.

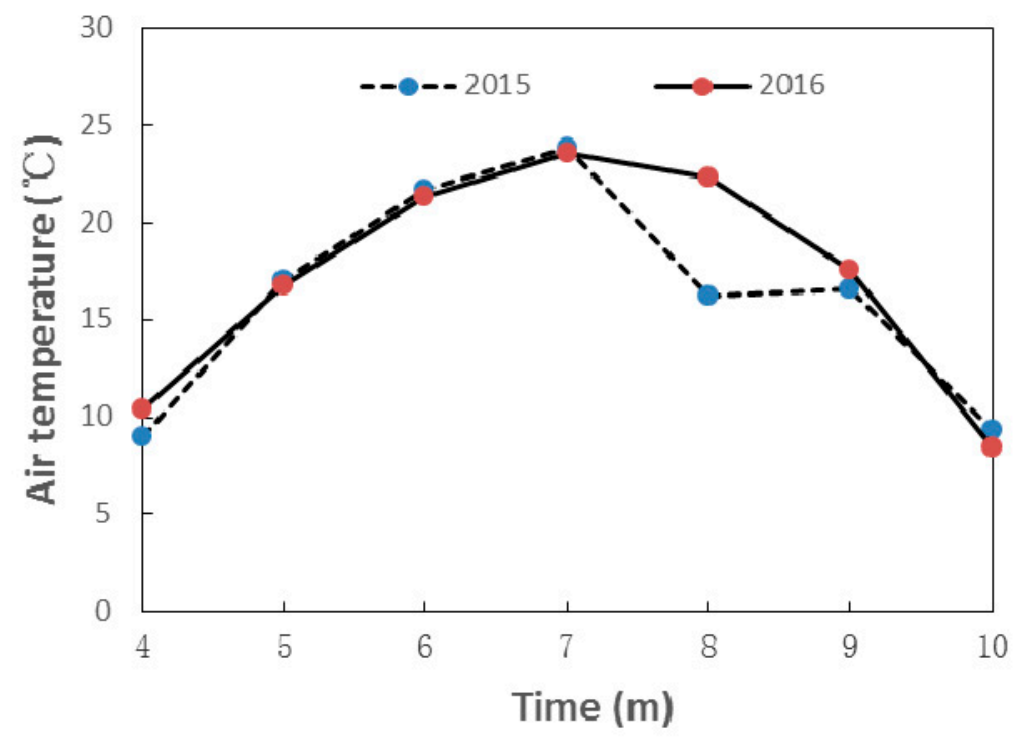

Figure A2. Air temperature (curve) of the experimental site in 2015 and 2016. 
Table A1. Aggressivity and competitiveness of maize relative to alfalfa for the nitrogen level (N) and root separation method (RS) between 2015 and 2016.

\begin{tabular}{|c|c|c|c|c|}
\hline Years & & & $A_{\text {ma }}$ & $\mathrm{NCR}_{\mathrm{ma}}$ \\
\hline \multirow{6}{*}{2015} & \multirow{3}{*}{ N0 } & NS & 2.30 & 4.46 \\
\hline & & NNS & 1.53 & 2.90 \\
\hline & & PSS & & \\
\hline & \multirow{3}{*}{ N1 } & NS & 1.48 & 2.39 \\
\hline & & NNS & 0.55 & 1.65 \\
\hline & & PSS & & \\
\hline \multirow{6}{*}{2016} & \multirow{3}{*}{ No } & NS & 2.07 & 3.88 \\
\hline & & NNS & 1.46 & 2.49 \\
\hline & & PSS & & \\
\hline & \multirow{3}{*}{ N1 } & NS & 2.26 & 3.05 \\
\hline & & NNS & 1.59 & 2.03 \\
\hline & & PSS & & \\
\hline
\end{tabular}

Ama: aggressivity of maize relative to alfalfa; NCRma: nitrogen competitive ratio of maize relative to alfalfa. Ama: aggressivity of maize relative to alfalfa; NCRma: nitrogen competitive ratio of maize relative to alfalfa. If Ama is greater than 0 , the competitive ability of maize exceeds that of maize in intercropping; if NCRma is greater than 1.0, the $\mathrm{N}$ competitive ability of maize will be greater than that of alfalfa in intercropping.

Table A2. Results of repeated measures ANOVA about effects of year (Y), nitrogen levels (N), and root separation method (RS) on nodule number and dry weight of alfalfa.

\begin{tabular}{ccccc}
\hline Factors & \multicolumn{2}{c}{ Nodule Number } & \multicolumn{2}{c}{ Dry Weight } \\
\hline $\mathrm{Y}$ & 106.39 & $<0.001^{* *}$ & 16.44 & $<0.001^{* *}$ \\
$\mathrm{~N}$ & 191.63 & $<0.001^{* *}$ & 285.27 & $<0.001^{* *}$ \\
$\mathrm{RS}$ & 82.74 & $<0.001^{* *}$ & 41.94 & $<0.001^{* *}$ \\
$\mathrm{Y} \times \mathrm{N}$ & 3.02 & 0.091 & 3.14 & $0.085 \mathrm{~ns}$ \\
$\mathrm{Y} \times \mathrm{RS}$ & 1.59 & 0.218 & 2.90 & $0.068 \mathrm{~ns}$ \\
$\mathrm{~N} \times \mathrm{RS}$ & 3.74 & $0.033^{*}$ & 6.25 & $0.005^{* *}$ \\
$\mathrm{Y} \times \mathrm{N} \times \mathrm{RS}$ & 2.59 & 0.089 & 1.27 & $0.293 \mathrm{~ns}$ \\
\hline
\end{tabular}

Note: ${ }^{*} p<0.05 ; * p<0.01$; and ns: $p>0.05$.
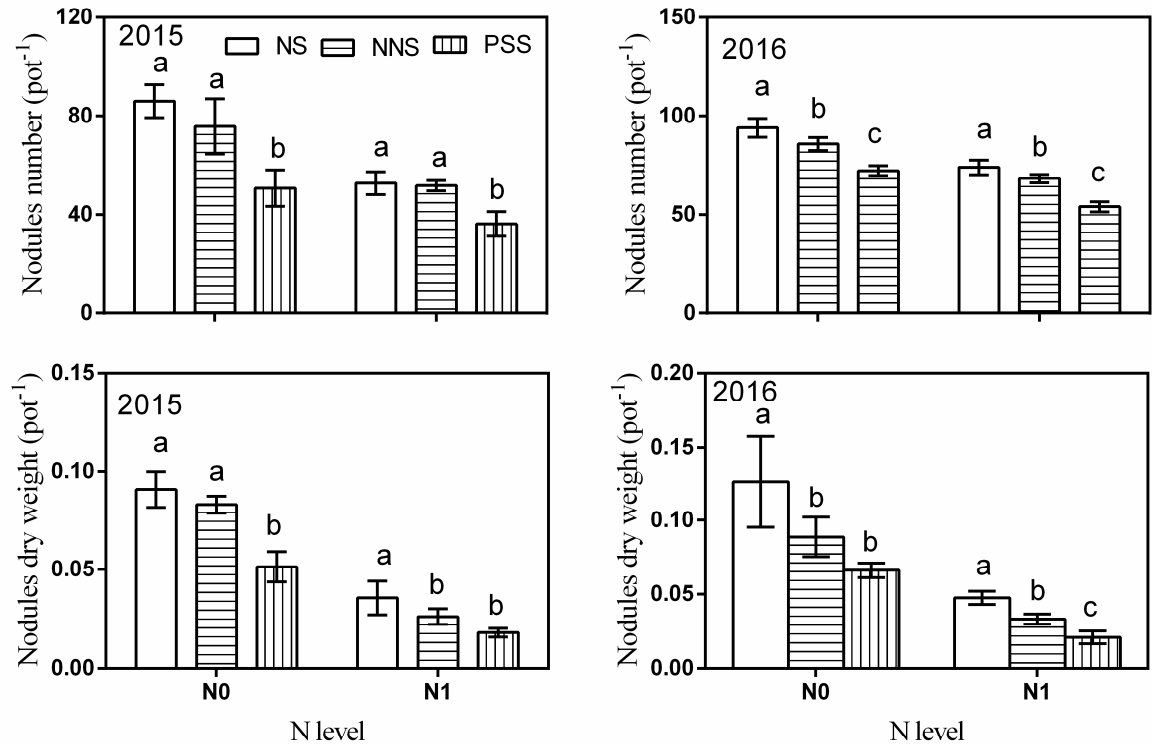

Figure A3. Effects of nitrogen levels and root separation patterns on nodule number and dry weight of alfalfa. Different lowercase letters show significant difference between root separation patterns under the same nitrogen levels at $p \leq 0.05$. 
Table A3. Results of repeated measures ANOVA about effects of year (Y), nitrogen levels (N), and root separation method (RS) on \%Ndfa and Ndfa of alfalfa.

\begin{tabular}{ccccc}
\hline Factors & \multicolumn{2}{c}{ Alfalfa $\%$ Ndfa } & \multicolumn{2}{c}{ Alfalfa Ndfa } \\
\hline $\mathrm{Y}$ & 7.42 & $<0.001^{* *}$ & 74.15 & $<0.001^{* *}$ \\
$\mathrm{~N}$ & 239.16 & $<0.001^{* *}$ & 54.60 & $<0.001^{* *}$ \\
$\mathrm{RS}$ & 339.12 & $<0.001^{* *}$ & 44.47 & $<0.001^{* *}$ \\
$\mathrm{Y} \times \mathrm{N}$ & 4.77 & $0.036^{*}$ & 7.39 & $<0.001^{* *}$ \\
$\mathrm{Y} \times \mathrm{RS}$ & 3.33 & $0.047^{*}$ & 2.30 & $0.114 \mathrm{~ns}$ \\
$\mathrm{~N} \times \mathrm{RS}$ & 24.55 & $<0.001^{* *}$ & 5.28 & $0.009^{* *}$ \\
$\mathrm{Y} \times \mathrm{N} \times \mathrm{RS}$ & 3.28 & $0.049^{*}$ & 1.15 & $0.328 \mathrm{~ns}$ \\
\hline \multicolumn{5}{r}{}
\end{tabular}
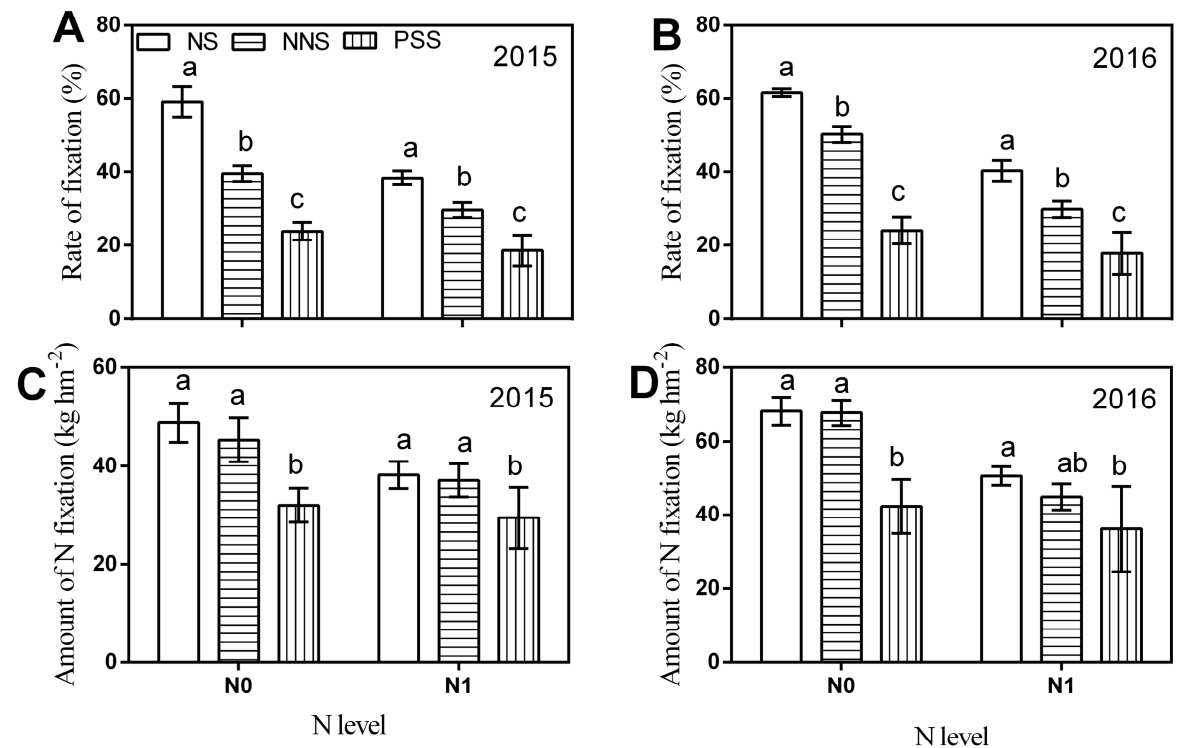

Figure A4. Effects of year, nitrogen levels and root separation method on $\% \mathrm{Ndfa}(\mathbf{A}, \mathbf{B})$ and $\mathrm{Ndfa}(\mathbf{C}, \mathbf{D})$ of alfalfa. Different lowercase letters show significant difference between root separation method under the same nitrogen levels at $p \leq 0.05$.

\section{References}

1. Tilman, D.; Cassman, K.G.; Matson, P.A.; Naylor, R.; Polasky, S. Agricultural sustainability and intensive production practices. Nature 2002, 418, 671-677. [CrossRef]

2. Celette, F.; Findeling, A.; Gary, C. Competition for nitrogen in an unfertilized intercropping system: The case of an association of grapevine and grass cover in a Mediterranean climate. Eur. J. Agron. 2009, 30, 41-51. [CrossRef]

3. Miriti, J.M.; Kironchi, G.; Esilaba, A.O.; Heng, L.K.; Gachene, C.K.K.; Mwangi, D.M. Yield and water use efficiencies of maize and cowpea as affected by tillage and cropping systems in semi-arid Eastern Kenya. Agric. Water Manag. 2012, 115, 148-155. [CrossRef]

4. Xia, H.Y.; Wang, Z.G.; Zhao, J.H.; Sun, J.H.; Bao, X.G.; Christie, P.; Zhang, F.S.; Li, L. Contribution of interspecific interactions and phosphorus application to sustainable and productive intercropping systems. Field Crop. Res. 2013, 154, 53-64. [CrossRef]

5. Sun, B.R.; Peng, Y.; Yang, H.Y.; Li, Z.J.; Gao, Y.Z.; Wang, C.; Yan, Y.L.; Liu, Y.M. Alfalfa (Medicago sativa L.)/maize (Zea mays L.) intercropping provides a feasible way to improve yield and economic incomes in farming and pastoral areas of northeast China. PLoS One 2014, 9, e110556. [CrossRef]

6. Kermah, M.; Franke, A.C.; Adjei-Nsiah, S.; Ahiabor, B.D.K.; Abaidoo, R.C.; Giller, K.E. N2-fixation and $\mathrm{N}$ contribution by grain legumes under different soil fertility status and cropping systems in the guinea savanna of northern ghana. Agric. Ecosyst. Environ. 2018, 261, 201-210. [CrossRef] 
7. Chu, G.X.; Shen, Q.R.; Cao, J.L. Nitrogen fixation and $\mathrm{N}$ transfer from peanut to rice cultivated in aerobic soil in an intercropping system and its effect on soil N fertility. Plant Soil 2004, 263, 17-27. [CrossRef]

8. Sierra, J.; Daudin, D. Limited $15 \mathrm{~N}$ transfer from stem-labelled leguminous trees to associated grass in an agroforestry system. Eur. J. Agron. 2010, 32, 240-242. [CrossRef]

9. Li, L.; Zhang, F.S.; Li, X.L.; Christie, P.; Sun, J.H.; Yang, S.C.; Tang, C.X. Interspecific facilitation of nutrient uptake by intercropped maize and faba bean. Nutr. Cycl. Agroecosyst. 2003, 65, 61-71. [CrossRef]

10. Jensen, E.S. Barley uptake of N deposited in the rhizosphere of associated field pea. Soil Biol. Biochem. 1996, 28, 159-168. [CrossRef]

11. Xiao, Y.B.; Li, L.; Zhang, F.S. Effect of root contact on interspecific competition and $\mathrm{N}$ transfer between wheat and fababean using direct and indirect ${ }^{15} \mathrm{~N}$ techniques. Plant Soil 2004, 262, 45-54. [CrossRef]

12. Sakai, R.H.; Ambrosano, E.J.; Negrini, A.C.A.; Trivelin, P.C.O.; Schammass, E.A.; Melo, P.C.T.D. N transfer from green manures to lettuce in an intercropping cultivation system. Acta Sci. Agron. 2011, 33, 679-686. [CrossRef]

13. Olujobi, O.J.; Oyun, M.B. Nitrogen Transfer from Pigeon Pea [Cajanus Cajan (L.) Misllp.] to Maize (Zea mays L.) In a Pigeon Pea/Maize Intercrop. Am. Int. J. Contemp. Res. 2012, 2, 115-120.

14. Zhang, H.; Zeng, F.P.; Zou, Z.G.; Zhang, Z.Q.; Li, Y.Z. Nitrogen uptake and transfer in a soybean/maize intercropping system in the karst region of southwest China. Ecol. Evol. 2017, 7, 8419-8426. [CrossRef]

15. Tang, Q.X.; Haile, T.; Liu, H.B.; Ren, T.Z.; Jiang, P.A.; Zhai, L.M.; Lei, B.K.; Liu, T.; Liu, E.K. Nitrogen uptake and transfer in broad bean and garlic strip intercropping systems. J. Integr. Agric. 2018, 1, 220-230. [CrossRef]

16. Moyer-Henry, K.A.; Burton, J.W.; Israel, D.W.; Rufty, T.W. Nitrogen transfer between plants: $\mathrm{A}^{15} \mathrm{~N}$ natural abundance study with crop and weed species. Plant Soil 2006, 282, 7-20. [CrossRef]

17. He, X.H.; Xu, M.G.; Qiu, G.Y.; Zhou, J.B. Use of ${ }^{15} \mathrm{~N}$ stable isotope to quantify nitrogen transfer between mycorrhizal plants. J. Plant. Ecol. 2009, 2, 107-118. [CrossRef]

18. Chalk, P.M.; Peoples, M.B.; Mcneill, A.M.; Boddey, R.M.; Unkovich, M.J.; Gardener, M.J.; Silva, C.F.; Chen, D.L. Methodologies for estimating nitrogen transfer between legumes and companion species in agro-ecosystems: A review of ${ }^{15} \mathrm{~N}$-enriched techniques. Soil Biol. Biochem. 2014, 73, 10-21. [CrossRef]

19. Erice, G.; Louahlia, S.; Irigoyen, J.J.; Sanchez-Diaz, M.; Avice, J.C. Biomass partitioning, morphology and water status of four alfalfa genotypes submitted to progressive drought and subsequent recovery. J. Plant. Physiol. 2010, 167, 114-120. [CrossRef]

20. Zhang, G.G.; Yang, Z.B.; Dong, S.T. Interspecific competitiveness affects the total biomass yield in an alfalfa and corn intercropping system. Field Crop. Res. 2011, 124, 66-73. [CrossRef]

21. Meng, L.B.; Zhang, A.Y.; Wang, F.; Han, X.G.; Wang, D.J.; Li, S.M. Arbuscular mycorrhizal fungi and rhizobium facilitate nitrogen uptake and transfer in soybean/maize intercropping system. Front. Plant. Sci. 2015, 6, 339. [CrossRef]

22. Shen, Q.R.; Chu, G.X. Bi-directional nitrogen transfer in an intercropping system of peanut with rice cultivated in aerobic soil. Biol. Fertil. Soil. 2004, 40, 81-87. [CrossRef]

23. Pirhofer-Walzl, K.; Rasmussen, J.; HøGh-Jensen, H.; Eriksen, J.; Søegaard, K.; Rasmussen, J. Nitrogen transfer from forage legumes to nine neighbouring plants in a multi-species grassland. Plant Soil 2012, 350, 71-84. [CrossRef]

24. Danso, S.K.A.; Hardarson, G.; Zapata, F. Misconceptions and practical problems in the use of ${ }^{15} \mathrm{~N}$ soil enrichment techniques for estimating $\mathrm{N}_{2}$ fixation. Plant Soil 1993, 152, 25-52. [CrossRef]

25. Yu, H.L.; Gao, Q.; Shao, Z.Q.; Ying, A.N.; Sun, Y.Y.; Liu, J.W.; Mao, W.; Zhang, B. Decreasing nitrogen fertilizer input had little effect on microbial communities in three types of soils. PLoS One 2016, 11, e0151622. [CrossRef]

26. Cui, T.T.; Li, Z.H.; Wang, S.J. Effects of in-situ straw decomposition on composition of humus and structure of humic acid at different soil depths. J. Soil Sediment. 2017, 17, 2391-2399. [CrossRef]

27. ISO. Soil Quality-Determination of Effective Cation Exchange Capacity (CEC) and Exchangeable Cations Using a Hexamminecobalt Trichloride Solution; ISO: Geneva, Switzerland, 2007; p. 23470.

28. Schlindwein, J.A.; Miotti, A.A.; Fioreliperira, E.C.; Pequeno, P.L.D.L.; Bortolon, L.; Marcolan, A.L. Adjustment of the expedite method for clay content determination in rondônia soils. Ciência Rural. 2011, 41, 2096-2100. [CrossRef]

29. FAO-ISRIC Guidelines for soil description, thirded, revised, food and agricultural organization. Rome. 1990. 
30. Fageria, N.K.; Baligar, V.C. Methodology for evaluation of lowland rice genotypes for nitrogen use efficiency. J. Plant Nutr. 2003, 26, 1315-1333. [CrossRef]

31. Thilakarathna, M.S.; Papadopoulos, Y.A.; Rodd, A.V.; Grimmett, M.; Fillmore, S.A.E.; Crouse, M.; Prithiviraj, B. Nitrogen fixation and transfer of red clover genotypes under legume-grass forage based production systems. Nutr. Cycl. Agroecosyst. 2016, 106, 233-247. [CrossRef]

32. Fan, J.L.; McConkey, B.G.; Wang, H.; Janzen, H.H. Root distribution by depth for temperate agricultural crops. Field Crop. Res. 2016, 189, 68-74. [CrossRef]

33. Li, Y.Y.; Yu, C.B.; Eng, X.C.; Li, C.J.; Sun, J.H.; Zhang, F.S.; Lambers, H.; Li, L. Intercropping alleviates the inhibitory effect of $\mathrm{N}$ fertilization on nodulation and symbiotic $\mathrm{N}_{2}$ fixation of faba bean. Plant Soil 2009, 323, 295-308. [CrossRef]

34. Wang, Z.K.; Zhao, X.N.; Wu, P.T.; He, J.Q.; Chen, X.L.; Gao, Y.; Cao, X.C. Radiation interception and utilization by wheat/maize strip intercropping systems. Agric. For. Meteor. 2015, 204, 58-66. [CrossRef]

35. Lambers, H.; Shane, M.W.; Cramer, M.D.; Pearse, S.J.; Veneklaas, E.J. Root structure and functioning for efficient acquisition of phosphorus: matching morphological and physiological traits. Ann. Bot. 2006, 98, 693-713. [CrossRef]

36. Gao, Y.Z.; Lynch, J.P. Reduced crown root number improves water acquisition under water deficit stress in maize (Zea mays L.). J. Exper. Bot. 2016, 67, 4545-4557. [CrossRef]

37. Gylfadóttir, T.; Helgadóttir, Á.; Høgh-Jensen, H. Consequences of including adapted white clover in northern European grassland: transfer and deposition of nitrogen. Plant Soil 2007, 297, 93-104. [CrossRef]

38. Ledgard, S.F. Nitrogen cycling in low input legume-based agriculture, with emphasis on legume/grass pastures. Plant Soil 2001, 228, 43-59. [CrossRef]

39. Salvagiotti, F.; Cassman, K.G.; Specht, J.E. Nitrogen uptake, fixation and response to fertilizer N in soybeans: A review. Field Crop. Res. 2008, 108, 1-13. [CrossRef]

40. Unkovich, M. Nitrogen fixation in Australian dairy systems: review and prospect. Crop Pasture Sci. 2012, 63, 787-804. [CrossRef]

41. Wang, X.Y.; Gao, Y.Z.; Zhang, H.L.; Shao, Z.Q.; Sun, B.R.; Gao, Q. Enhancement of rhizosphere citric acid and decrease of $\mathrm{NO}_{3}{ }^{-} / \mathrm{NH}_{4}{ }^{+}$ratio by root interactions facilitate $\mathrm{N}$ fixation and transfer. Plant Soil 2019. [CrossRef]

42. Zhang, H.; Wang, X.; Gao, Y.; Sun, B. Short-term N transfer from alfalfa to maize is dependent more on arbuscular mycorrhizal fungi than root exudates in N deficient soil. Plant Soil 2020, 446, 23-41. [CrossRef]

43. Sun, T.; Li, Z.; Wu, Q.; Sheng, T.; Du, M. Effects of alfalfa intercropping on crop yield, water use efficiency, and overall economic benefit in the Corn Belt of Northeast China. Field Crop. Res. 2018, 216, 109-119. [CrossRef]

44. Li, L. Intercropping enhances agroecosystem services and functioning: Current knowledge and perspectives. Chin. J. Eco-Agric. 2016, 24, 403-415.

45. Brooker, R.W.; Bennett, A.E.; Cong, W.F.; Daniell, T.J.; George, T.S.; Hallett, P.D.; Li, L. Improving intercropping: a synthesis of research in agronomy, plant physiology and ecology. New Phytol. 2015, 206, 107-117. [CrossRef] 